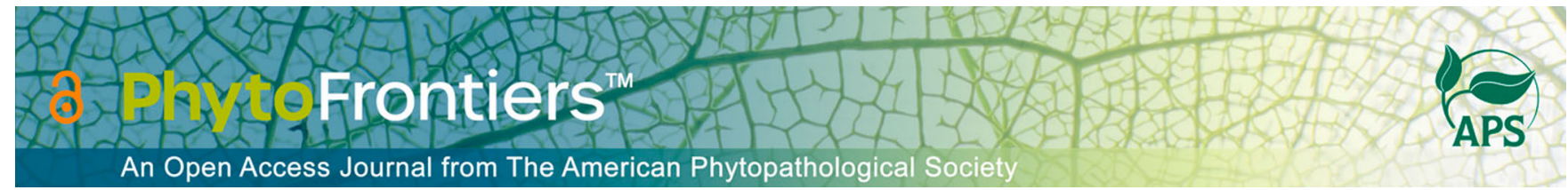

\title{
Research
}

\section{Virulence Diversity of Phakopsora pachyrhizi in Mexico}

\author{
Julio César García-Rodríguez ${ }^{1}$ | Zeferino Vicente-Hernández ${ }^{2}$ | Manuel Grajales-Solís ${ }^{3}$ | \\ Naoki Yamanaka ${ }^{4,+}$ (D) |
}

1 Instituto Nacional de Investigaciones Forestales, Agrícolas y Pecuarias, Campo Experimental Las Huastecas (INIFAP-Las Huastecas), Carr. Tampico-Mante km 55, Altamira, Tamaulipas, C.P. 89610, Mexico

2 Professional service provider, 16 de Septiembre 1404 , Col. Independecia, Altamira, Tamaulipas, C.P. 89602 , Mexico

${ }^{3}$ Instituto Nacional de Investigaciones Forestales, Agrícolas y Pecuarias, Campo Experimental Rosario Izapa (INIFAP-Rosario Izapa), Carr. Tapachula-Cacahoatán km 18 Tuxtla Chico, Chiapas, C.P. 30870 , Mexico

4 Japan International Research Center for Agricultural Sciences (JIRCAS), 1-1 Ohwashi, Tsukuba, Ibaraki 305-8686, Japan

\footnotetext{
† Corresponding author: N. Yamanaka; naokiy@affrc.go.jp
}

Accepted for publication 28 July 2021.

\section{Funding}

JIRCAS and INIFAP provided the financial support to perform this research.

$e$-Xtra: One supplementary figure and one supplementary datasheet are published online.

The author(s) declare no conflict of interest

\begin{abstract}
Asian soybean rust, caused by the pathogen Phakopsora pachyrhizi, is the main soybean disease in Mexico and worldwide, threatening its production. Knowledge about the virulence of Mexican rust populations (MRPs) is crucial to develop or introduce soybean cultivars with resistance to this disease. This study investigated the geographic variation in the virulence of 19 MRPs collected in two states of Mexico (Tamaulipas and Chiapas) using a set of 12 differential soybean varieties. The inoculation of MRPs showed that there was no large difference in virulence to differentials carrying Rpp4 or Rpp5 between MRPs from the two states. However, a contrasting phenotype was observed on Rpp1, Rpp1-b, Rpp2, and Rpp3. In the comparative analysis of virulence profiles with 157 and 20 P. pachyrhizi samples from South America and Asia, respectively, the MRPs from Chiapas form an isolated cluster, including the Tamaulipas state. The MRPs from Tamaulipas clustered with South American samples because of common characteristics, such as virulence to Rpp1 and avirulence to Rpp1-b. However, opposite reactions on Rpp1 and Rpp1-b that have been reported in major U.S. pathogens were also observed in Chiapas samples. A common trend between Chiapas and major U.S pathogens was also observed in Rpp3. The main conclusion of the present study is that the $1,000-\mathrm{km}$ distance between these two states in Mexico makes a big difference in the virulence of Asian soybean rust.
\end{abstract}

Keywords: Glycine max, Asian soybean rust, virulence, resistance gene, Rpp

Soybean (Glycine max (L.) Merr.) is one of the most economically important crops worldwide and has become one of the top-traded commodities (Hartman et al. 2011). Mexico is the third-largest soybean importer country in the world. In 2019-2020, Mexico imported 6 million metric tons of soybean and produced only $3.75 \%$ of their consumption of 6.25 million metric tons (USDA 2021). From 2003 to 2016, the planted area of soybean increased from 71,260 to 280,130 ha, and production reached 509,110 metric tons (SAGARPA 2017). The states with major soybean production during the 2020 planting season in Mexico were Tamaulipas, Campeche, San Luis Potosi, Chiapas, and Sinaloa (SIAP 2021). It is estimated that by 2030, soybean production in Mexico will 
reach 0.64 million metric tons (SAGARPA 2017), implying an increase in planted areas within the highest production states.

Asian soybean rust (ASR), caused by the pathogen Phakopsora pachyrhizi Syd. \& P. Syd. is one of the main soybean diseases worldwide and threatens soybean production in tropical and subtropical regions. The first occurrence of ASR on the American continent was reported in 2001 in Paraguay and Brazil (Yorinori et al. 2005) and by 2004 in Colombia and the United States (Schneider et al. 2005). In Mexico, the disease appeared in 2005 (Cárcamo-Rodríguez et al. 2006). The yield reduction by ASR varies from 10 to $80 \%$ (Li et al. 2010; Pennisi 2010), but when environmental conditions are favorable for P. pachyrhizi, development can be more than $80 \%$ (Rosa et al. 2015). In Mexico, yield losses caused by ASR disease range from 25 to $80 \%$ (Terán-Vargas et al. 2007), which makes chemical control necessary (Yáñez-López et al. 2015). Use of soybean varieties resistant to $P$. pachyrhizi is considered a cost-effective and environmentally friendly strategy for ASR disease management. The adoption of ASR-resistant cultivars is estimated to reduce current fungicide costs for farmers by US $\$ 112$ million to US $\$ 253$ million in Paraguay and US\$1.14 billion in Brazil (Ishikawa-Ishiwata and Furuya 2021a, b).

Eight Rpp (resistance to P. pachyrhizi) genes named Rppl to $R p p 7$ and Rppl-b have been reported to confer resistance to the ASR pathogen (Childs et al. 2018; Garcia et al. 2008; Hossain et al. 2015; Li et al. 2012; Ray et al. 2009). However, it is important to know the characteristics of pathogens of local $P$. pachyrhizi populations to effectively incorporate $R p p$ genes into soybean-breeding programs because the Rpps are racespecific and could be ineffective depending on the $P$. pachyrhizi strains present (Hartwig and Bromfield 1983). Therefore, soybean varieties carrying different known Rpps have been used to examine the virulence of $P$. pachyrhizi populations in South
American countries (Akamatsu et al. 2013, 2017; Stewart et al. 2019). These reports show that South American ASR pathogen populations are highly virulent and diverse in their virulence, with no clear trend in geographic or annual characteristics.

A large difference in the virulence of four Mexican rust populations (MRPs) collected in 2015 was observed in a previous study (García-Rodríguez et al. 2017). However, geographical and yearly changes in virulence on MRPs have not yet been studied. Thus, the present study aimed to investigate the characteristics of MRPs collected in two major Mexican soybean production states (Tamaulipas and Chiapas) during multiple soybean-growing seasons.

\section{MATERIALS AND METHODS}

\section{Pathogen and plant materials}

A total of 19 ASR samples were used in the present study: 9 ASR samples were collected during the 2016-2017 winter, 2018 summer, and 2018-2019 winter in Tamaulipas, and 10 ASR populations were collected in the 2018 summer in Chiapas (Table 1). Five of 19 MRPs (MRP-34, -35, -37, -40, and -44) were also used in the previous study (García-Rodríguez et al. 2019). Data of four MRPs (MRP-4, -13, -16, and -19) collected during the 2015 summer in a previous study (García-Rodríguez et al. 2017) were used for comparison. At each sampling site, 10 to 20 ASR-infected leaves were collected and placed in a plastic bag, and bags were kept in a styrene foam box while completing the day's collection. In the laboratory, urediniospores were collected by tapping the leaflets over a paraffin paper. Then, the harvested urediniospores were multiplied immediately by inoculating leaves of ASR-susceptible cultivar BRS 154 according

TABLE 1

\begin{tabular}{|c|c|c|c|c|c|c|}
\hline \multicolumn{7}{|c|}{ TABLE 1} \\
\hline \multicolumn{7}{|c|}{ Mexican Phakopsora pachyrhizi samples used in this study } \\
\hline Growing season & State & Sample ID ${ }^{t}$ & Municipality & Location & Sampling date & Host variety \\
\hline \multirow[t]{4}{*}{2015 summer } & Tamaulipas & $\mathrm{MRP}-4^{\mathrm{u}}$ & Reynosa & Reynosa de Diaz & Dec. 3,2015 & Huasteca 400 \\
\hline & & MRP-13 ${ }^{\mathrm{u}}$ & Matamoros & Ejido Ranchitos & Dec. 4,2015 & Vernal \\
\hline & & MRP $-16^{\mathrm{u}}$ & Altamira & Ejido El 40 & Dec. 7,2015 & Huasteca 200 \\
\hline & San Luis Potosi & MRP $-19^{u}$ & Tamuin & Tamuin & Dec. 8,2015 & Huasteca 400 \\
\hline \multirow[t]{4}{*}{ 2016-2017 winter } & Tamaulipas & MRP- $23^{v}$ & Altamira & Ejido Colonias & March 17, 2017 & $-{ }^{\mathrm{w}}$ \\
\hline & & MRP-24v & Altamira & Rancho El Venado & March 17, 2017 & - \\
\hline & & MRP- $25^{\mathrm{V}}$ & Altamira & Rancho Las Lolas & March 17, 2017 & - \\
\hline & & MRP-26 & Altamira & Ejido Miradores & March 17, 2017 & - \\
\hline \multirow[t]{13}{*}{2018 summer } & Chiapas & MRP-27 & Tapachula & Tinajas $2 \mathrm{da}$ Seccion & Nov. 8,2018 & Huasteca 400 \\
\hline & & MRP-28 & Tapachula & Ejido J. Manuel G. & Nov. 8,2018 & Valiosa $\mathrm{a}^{\mathrm{x}}$ \\
\hline & & MRP-29 & Tapachula & Tinajas $2 \mathrm{da}$ Seccion & Nov. 8,2018 & Luziana \\
\hline & & MRP-30 & Tapachula & Ejido Los Llanos & Nov. 9, 2018 & Cristalina $^{\mathrm{x}}$ \\
\hline & & MRP-31 & Tapachula & Ejido El Manzano & Nov. 9, 2018 & Luziana \\
\hline & & MRP-32 & Tapachula & Ejido Los Llanos & Nov. 9, 2018 & Valiosa $a^{x}$ \\
\hline & & MRP-34 & Tapachula & Tinajas 1ra Seccion & Nov. 8,2018 & Cristalina $^{\mathrm{x}}$ \\
\hline & & MRP- $35^{\mathrm{u}}$ & Tapachula & Tinajas 1ra Seccion & Nov. 8,2018 & Luziana \\
\hline & & MRP-37" & Tapachula & Ejido El Manzano & Nov. 9, 2018 & Valiosa $^{\mathrm{x}}$ \\
\hline & & MRP-38 & Tapachula & Ejido Tapachula & Nov. 9, 2018 & Luziana \\
\hline & Tamaulipas & MRP-39 & Altamira & Ejido Cuauhtemoc & Nov. 27, 2018 & - \\
\hline & & MRP $-40^{\mathrm{u}}$ & Altamira & Ejido Cuauhtemoc & Nov. 27, 2018 & - \\
\hline & & MRP-41 & Altamira & Ejido Esteros & Nov. 27, 2018 & - \\
\hline \multirow[t]{2}{*}{ 2018-2019 winter } & Tamaulipas & MRP- $44^{\mathrm{u}, \mathrm{y}}$ & Altamira & Las Huastecas ${ }^{\mathrm{z}}$ & Jan. 28, 2019 & Huasteca 400 \\
\hline & & MRP $-45^{\mathrm{v}}$ & Altamira & Las Huastecas ${ }^{\mathrm{Z}}$ & March 20, 2019 & Huasteca 600 \\
\hline \multicolumn{7}{|c|}{ Strains of soybean rust collected in Mexico were coded as MRP (Mexican rust population) with consecutive numbers. } \\
\hline \multicolumn{7}{|c|}{ u These samples were isolated in previous studies (García-Rodríguez et al. 2017, 2019). } \\
\hline \multicolumn{7}{|c|}{$\mathrm{v}$ These samples were isolated from voluntary soybean plants. } \\
\hline \multicolumn{7}{|c|}{ w $-=$ no data. } \\
\hline \multicolumn{7}{|c|}{$\mathrm{x}$ Corresponds to a transgenic variety (GMO). } \\
\hline \multicolumn{7}{|c|}{ y The sample was collected in a greenhouse. } \\
\hline z INIFAP - Las Hu & & & & & & \\
\hline
\end{tabular}


to the leaf-culture method (Yamanaka et al. 2020) to use fresh urediniospores for the following experimental inoculation. We used a set of 12 differential soybean varieties consisting of 10 varieties carrying a single resistance gene (Rpp1, Rpp2, Rpp3, $R p p 4, R p p 5$, Rpp6, or Rpp1-b); one Rpp-pyramidal line carrying $R p p 2, R p p 4$, and $R p p 5$; and one susceptible variety (Yamanaka et al. 2020; Table 2). Three plants per pot of each variety were grown in a greenhouse at a temperature between 22 and $28^{\circ} \mathrm{C}$. Styrofoam pots with a diameter of $15 \mathrm{~cm}$ and height of $13.5 \mathrm{~cm}$ were filled with the mixture of soil $(80 \%)$, peat moss $(15 \%)$, and perlite (5\%) and used for cultivation. A fertilizer, Soludrip (El Surco, Tampico), solution (0.65 g/liter) was applied once a week at $150 \mathrm{ml}$ per pot.

\section{Inoculation and evaluation}

The first trifoliate leaflets were detached and then inoculated with a urediniospore suspension $\left(\sim 5 \times 10^{4}\right.$ urediniospores $\left./ \mathrm{ml}\right)$ prepared according to Yamanaka et al. (2020). The inoculated leaflets were placed in Petri dishes and held in a growth chamber: $21^{\circ} \mathrm{C}$, photoperiod of 12-h light of approximately 3,000 lux provided by fluorescent lamps. One leaflet of the first trifoliate in each plant was inoculated with each MRP. Thus, three leaflets derived from three different plants were used in each differential variety. Two weeks after inoculation, the sporulation level (SL) was assessed by the naked eye and classified as none (0), little (1), moderate (2), or abundant (3). The urediniospores were removed with a paintbrush and, under a stereomicroscope, the number of uredinia per lesion (NoU) was calculated from the number count of uredinia in up to 30 lesions. The original SL and NoU data of 19 MRPs in 12 differential varieties is provided in the supplementary datasheet. The reaction type of each variety was classified as resistant (R), intermediate (IM), or susceptible (S) according to the lesion presence and values of SL and NoU (Table 3). Namely, we scored the reaction as $\mathrm{R}$ if no lesion was observed (there was no such case in this study) or if $\mathrm{SL}=0$ or 1 and $\mathrm{NoU}<1.2$ were obtained from observed lesions. S was decided if $\mathrm{SL}=2$ or 3 and $\mathrm{NoU} \geq 1.2$ were observed. We scored the reaction as IM if we observed $\mathrm{SL}=2$ or 3 and $\mathrm{NoU}<1.2$, or $\mathrm{SL}=0$ or 1 and NoU $\geq 1.2$ (Table 3).

\section{Clustering analysis}

The R/IM/S reaction profile of MRPs obtained in this study was compared with the 157 South American and 20 Asian P. pachyrhizi populations reported previously (Akamatsu et al. 2017; Stewart et al. 2019) and 4 MRPs previously collected in Mexico (García-Rodríguez et al. 2017). The South Ameri- can samples consisted of the previously reported samples from Argentina (44), Brazil (58), Paraguay (43), and Uruguay (12). The Asian populations included 20 samples from Bangladesh (Hossain and Yamanaka 2019) and 8 samples from Japan (Yamanaka et al. 2015a; Yamaoka et al. 2014). For the clustering analysis, the three reaction types were changed to numerical scores: $\mathrm{R}=0, \mathrm{IM}=1$, and $\mathrm{S}=2$. Distance matrices were prepared by calculating Euclidian distances between samples in R software version 3.6.1 (R Development Core Team 2019). A dendrogram based on the unweighted pair group method with an arithmetic mean was also constructed with the same software. The pvclust package of $\mathrm{R}$ software was run to assess the uncertainty of hierarchical cluster analysis. This analysis calculates approximately unbiased probability values (AU $P$ values) for each cluster using 10,000 multiscale bootstrap resampling techniques (Suzuki and Shimodaira 2006). We carried out clustering analysis for Mexican samples alone and Mexican samples together with Asian and South American samples.

\section{RESULTS}

\section{General features of Mexican ASR pathogen}

Reaction patterns on the differential varieties in 19 MRPs collected in both Tamaulipas and Chiapas states during the 20162017 winter to the 2018-2019 winter are summarized in Fig. 1, including the four MRPs sampled in Tamaulipas and San Luis Potosi states in the 2015 summer. Frequencies of resistant reactions observed in the differential varieties by infections of Mexican and South American ASR samples are shown in Table 4. There was no variation in virulence by the MRPs on three of the 12 differential varieties. All MRPs were virulent to PI 587886 (Rppl) and BRS 154 (susceptible control) and avirulent to No6-12-1

\section{TABLE 3}

Classification criteria of infection type in differential varieties for leaf-culture experiment ${ }^{\mathrm{Z}}$

\begin{tabular}{lccl}
\hline $\begin{array}{l}\text { Presence }(+) \text { or absence } \\
(-) \text { of lesion }\end{array}$ & SL & NoU & \multicolumn{1}{c}{ Infection type } \\
\hline- & - & - & Resistant (Immune) \\
+ & 0 or 1 & $<1.2$ & Resistant \\
+ & 2 or 3 & $<1.2$ & Intermediate \\
+ & 0 or 1 & $1.2 \leq$ & Intermediate \\
+ & 2 or 3 & $1.2 \leq$ & Susceptible \\
\hline
\end{tabular}

${ }^{\mathrm{z}}$ Classification criteria from Yamanaka et al. (2013). SL $=$ sporulation level and $\mathrm{NoU}=$ number of uredinia per lesion.

TABLE 2

Soybean differential varieties used for determining the virulence of Mexican Phakopsora pachyrhizi samples

\begin{tabular}{|c|c|c|c|c|c|}
\hline ID & PI number & Name of variety/line & Resistance (Rpp) gene & Origin & Reference \\
\hline RDV1 & PI 200492 & Komata & Rppl & Japan & Hartwig and Bromfield 1983 \\
\hline RDV2 & PI 587886 & Bai Dou & Rppl & China & Ray et al. 2009 \\
\hline RDV3 & PI 230970 & No. 3 & Rpp2 & Japan & Hartwig and Bromfield 1983 \\
\hline RDV4 & PI 462312 & Ankur & Rpp3 & India & Hartwig and Bromfield 1983 \\
\hline RDV5 & PI 416764 & Akasaya & Rpp3 & Japan & Hossain et al. 2015 \\
\hline RDV6 & PI 459025 & Bing Nan & Rpp4 & China & Hartwig 1986 \\
\hline RDV7 & PI 200526 & Shiranui & Rpp5 & Japan & Garcia et al. 2008 \\
\hline RDV8 & PI 567102B & MARIF 2767 & Rpp6 & Indonesia & Li et al. 2012 \\
\hline RDV9 & PI 587880A & Huang Dou & $R p p 1-b$ & China & Ray et al. 2009 \\
\hline RDV10 & PI 594767A & Zhao Ping Hei Dou & $R p p 1-b$ & China & Hossain et al. 2015 \\
\hline RDV11 & - & BRS 154 & (None) & Brazil & Akamatsu et al. 2013 \\
\hline RDV12 & - & No6-12-1 & $R p p 2+R p p 4+R p p 5$ & Japan & Yamanaka et al. 2013, 2015b \\
\hline
\end{tabular}


$(R p p 2+R p p 4+R p p 5)$. Different reaction types were observed between the MRPs on the nine remaining differentials, even though only one or two MRPs were virulent to bring susceptible reaction in PI 416764 (Rpp3), PI 459025 (Rpp4), PI 200526 (Rpp5), and PI 567102B (Rpp6; Fig. 1B). As a result, these four varieties show high frequencies $(65.2$ to $95.7 \%)$ of phenotype resistant against MRPs, and these frequencies were higher than those observed in South America (Table 4). In five varieties-
PI 200492 (Rppl), PI 587880A (Rppl-b), PI 594767A (Rppl$b)$, PI 230970 (Rpp2), and PI 462312 (Rpp3)—frequencies of resistant reaction were moderate (30.4 to $52.2 \%$ ) as a Mexican ASR pathogen, but the regional tendency was clear after analysis (Fig. 1B; Table 4) by dividing MRPs into two major clusters (Fig. 1A). There was a virulence variation of MRPs on differential varieties/lines carrying seven kinds of single $R p p$, whereas no single-Rpp carrying variety was resistant to all tested

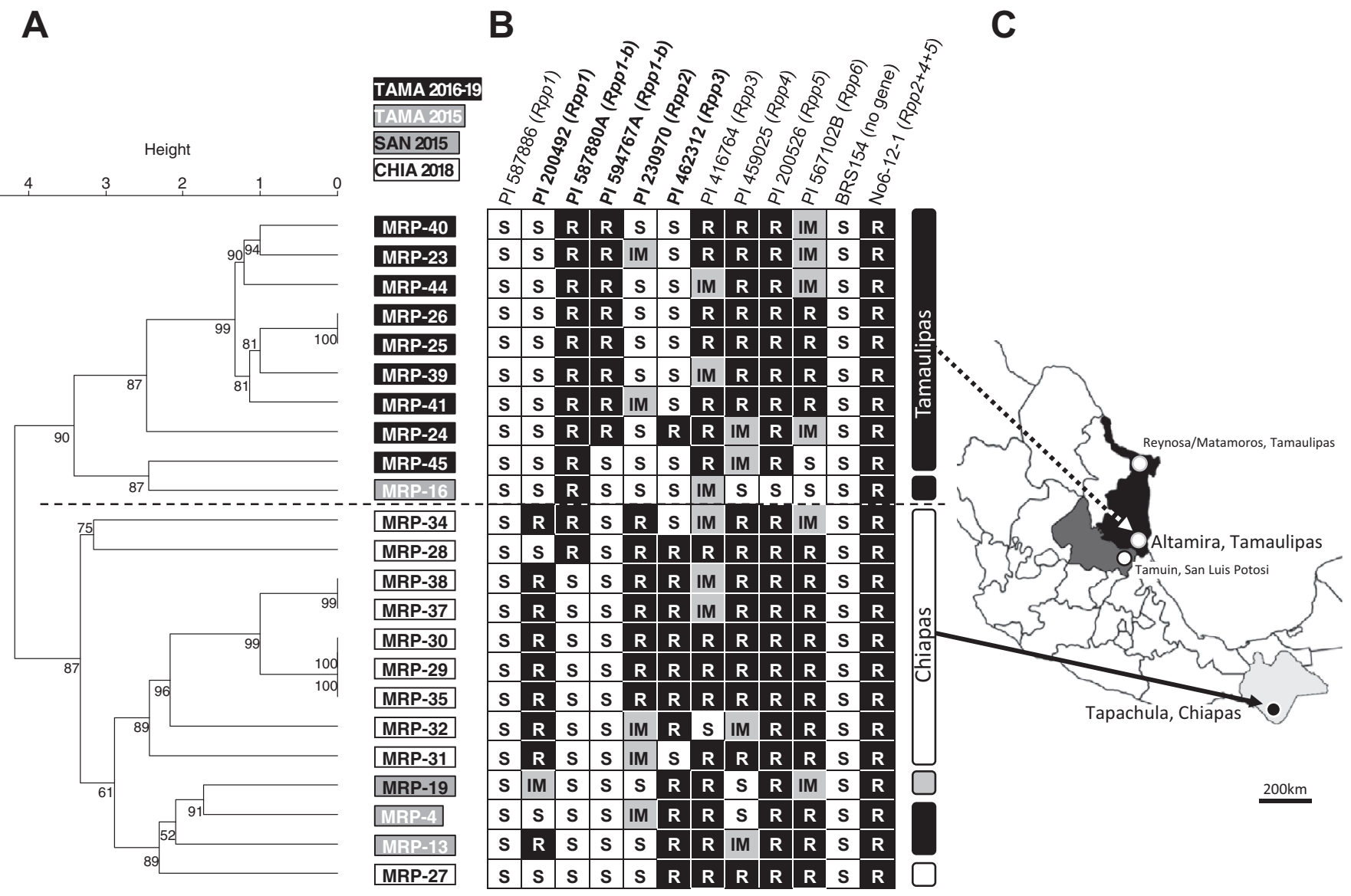

FIGURE 1

Characteristics of 9 and 10 pathogenic samples, respectively, from Tamaulipas (TAMA) and Chiapas (CHIA) states in 2016 to 2019 with four samples reported previously. Dendrogram showing relationship $(\mathbf{A})$; reaction pattern of 12 differential soybean varieties (B); and sampling location $(\mathbf{C})$ are shown. The numbers at the nodes in dendrogram indicate approximately unbiased $P$ values ( $>60 \%)$ generated by 10,000 multiscale bootstrap resamplings. R, IM, and S mean resistant, intermediate, and susceptible, respectively. One sample, MRP-19 of 2015, was collected from San Luis Potosi (SAN) state.

TABLE 4

Frequency of resistant reactions to Phakopsora pachyrhizi samples from Tamaulipas and Chiapas states ${ }^{\mathrm{Z}}$

\begin{tabular}{|c|c|c|c|c|c|c|c|c|c|c|c|c|}
\hline $\begin{array}{l}\text { Region (no. of } \\
\text { samples) }\end{array}$ & $\begin{array}{c}\text { PI } 587886 \\
\text { Rppl }\end{array}$ & $\begin{array}{c}\text { PI } 200492 \\
\text { Rppl }\end{array}$ & $\begin{array}{c}\text { PI 587880A } \\
\text { Rppl-b }\end{array}$ & $\begin{array}{c}\text { PI 594767A } \\
\text { Rppl-b }\end{array}$ & $\begin{array}{c}\text { PI } 230970 \\
\quad R p p 2\end{array}$ & $\begin{array}{c}\text { PI } 462312 \\
\text { Rpp } 3\end{array}$ & $\begin{array}{c}\text { PI } 416764 \\
\text { Rpp3 }\end{array}$ & $\begin{array}{c}\text { PI } 459025 \\
\text { Rpp } 4\end{array}$ & $\begin{array}{c}\text { PI } 200526 \\
\text { Rpp } 5\end{array}$ & $\begin{array}{c}\text { PI } 567102 \mathrm{~B} \\
\quad \text { Rpp6 }\end{array}$ & $\begin{array}{c}\text { BRS154 } \\
-\end{array}$ & $\begin{array}{l}\text { No6-12-1 } \\
\text { Rpp2,4,5 }\end{array}$ \\
\hline Mexico (23) & $0.0 \%$ & $39.1 \%$ & $52.2 \%$ & $34.8 \%$ & $30.4 \%$ & $52.2 \%$ & $69.6 \%$ & $69.6 \%$ & $95.7 \%$ & $65.2 \%$ & $0.0 \%$ & $100.0 \%$ \\
\hline Tamaulipas (13) & $0.0 \%$ & $7.7 \%$ & $76.9 \%$ & $61.5 \%$ & $0.0 \%$ & $30.8 \%$ & $76.9 \%$ & $53.8 \%$ & $92.3 \%$ & $46.2 \%$ & $0.0 \%$ & $100.0 \%$ \\
\hline Chiapas (10) & $0.0 \%$ & $80.0 \%$ & $20.0 \%$ & $0.0 \%$ & $70.0 \%$ & $80.0 \%$ & $60.0 \%$ & $90.0 \%$ & $100.0 \%$ & $90.0 \%$ & $0.0 \%$ & $100.0 \%$ \\
\hline South America (157) & $11.1 \%$ & $4.0 \%$ & $85.1 \%$ & $87.6 \%$ & $23.2 \%$ & $41.4 \%$ & $30.1 \%$ & $46.6 \%$ & $76.6 \%$ & $53.3 \%$ & $0.0 \%$ & $98.3 \%$ \\
\hline Argentina (44) & $4.9 \%$ & $2.6 \%$ & $90.9 \%$ & $85.7 \%$ & $17.5 \%$ & $52.4 \%$ & $11.1 \%$ & $55.6 \%$ & $57.1 \%$ & $60.0 \%$ & $0.0 \%$ & $100.0 \%$ \\
\hline Brazil (58) & $8.6 \%$ & $1.8 \%$ & $77.2 \%$ & $87.5 \%$ & $28.6 \%$ & $45.6 \%$ & $32.7 \%$ & $48.2 \%$ & $84.2 \%$ & $46.2 \%$ & $0.0 \%$ & $92.3 \%$ \\
\hline Paraguay (43) & $23.8 \%$ & $9.3 \%$ & $85.4 \%$ & $86.0 \%$ & $23.3 \%$ & $36.6 \%$ & $51.2 \%$ & $50.0 \%$ & $83.7 \%$ & $93.3 \%$ & $0.0 \%$ & $100.0 \%$ \\
\hline Uruguay (12) & $0.0 \%$ & $0.0 \%$ & $100.0 \%$ & $100.0 \%$ & $16.7 \%$ & $0.0 \%$ & $0.0 \%$ & $0.0 \%$ & $83.3 \%$ & $0.0 \%$ & $0.0 \%$ & $100.0 \%$ \\
\hline
\end{tabular}

${ }^{\mathrm{z}}$ Those of all Mexican samples and 157 South American samples (44 Argentine, 58 Brazilian, 43 Paraguayan, and 12 Uruguayan samples; Akamatsu et al. 2017; Stewart et al. 2019) are also shown. Four Mexican samples previously reported (García-Rodríguez et al. 2017) are included in this analysis. Tamaulipas samples include 12 samples from Tamaulipas and 1 sample from San Luis Potosi state. The frequency $(\%)$ in this table indicates the frequency at which resistance reactions (including immunity) were observed in the number of inoculated $P$. pachyrhizi samples; $0 \%$ indicates that only intermediate or susceptible types were observed. PI numbers indicate differential varieties having a single resistance gene, and $R p p$ numbers indicate resistance genes. 
MRPs. Rpp5 in PI 200526 was effective against $95.7 \%$ of MRPs (Table 4). Only No6-12-1 carrying three Rpps showed resistance to all MRPs.

\section{Characteristics of ASR pathogen from two states}

Most of the MRPs collected from 2016 to 2019 in Tamaulipas were virulent to Rppl of PI 200492, Rpp2, and Rpp3 of PI 462312, similar to what was observed in the MRP-16 Tamaulipas sample in 2015 (Fig. 1B; Supplementary Fig. S1). In contrast, most of the MRPs of Chiapas were avirulent to Rppl of PI 200492, Rpp2, and Rpp3 of PI 462312. This opposite reaction pattern between the two states was also observed in Rppl-b: Most Tamaulipas samples were avirulent to Rpp 1- $b$, but Chiapas samples were predominantly virulent to this gene. These characteristics illustrate the major differences between the virulence of samples from Tamaulipas in the 2016 to 2019 period compared with those from Chiapas in the summer of 2018.

The clustering analysis of $23 \mathrm{MRPs}$ reflected the difference between the two states by making two major clusters: One consisted of 10 Tamaulipas MRPs and another consisted of all 10 Chiapas MRPs of 2018 and the three 2015 MRPs from Tamaulipas or San Luis Potosi (Fig. 1A). Cluster analysis with 20 Asian and 157 South American samples resulted in all 10 Chiapas MRPs and 3 MRPs of 2015 on an isolated cluster, with a few South American and Japanese samples, and apart from ASR samples from other countries (Fig. 2). All MRPs of Tamaulipas except for MRP-24 were clustered with South American samples but distinguished from Uruguayan samples. MRP-24 located apart from the major Tamaulipas cluster showed $\mathrm{R}$ reaction in PI 462312 (Rpp3) only in the Tamaulipas samples of 2016 to 2019 (Fig. 1B).

\section{Changes of virulence in Mexican ASR pathogen after 2015}

Three of four MRPs in 2015 (MRP-4, MRP-16, and MRP-19) were virulent to Rpp4, but MRP-13 was partially virulent to this gene. None of the 19 MRPs of 2016 to 2019 was virulent to Rpp4, and only 3 MRPs (MRP-24, MRP-45, and MRP-32) were partially virulent to Rpp4 (Fig. 1B). MRP-16 was also virulent to Rpp5; however, none of the 2016 to 2019 MRPs were virulent to this gene. All four MRPs in 2015 were virulent to Rppl-b of PI 594767A, but eight MRPs from Tamaulipas in this study were avirulent to it (Fig. 1). Rppl-b of PI 594767A was the only effective gene to bring an immune or resistant phenotype against highly virulent MRP-16, but at least 3 Rpps were effective against 19 MRPs of 2016 to 2019 in Mexico. MRP-4, -13, and -19 derived from Tamaulipas or San Luis Potosi in 2015 had different virulence from Tamaulipas samples in 2016 to 2019 on Rppl-b

\section{FIGURE 2}

Dendrogram showing the relationship between the 23 Mexican (Tamaulipas and Chiapas), 20 Asian (Japan and Bangladesh), and 157 South American (Brazil, Argentina, Paraguay, and Uruguay) Phakopsora pachyrhizi populations based on their virulence to differential soybean varieties. Data of Bangladeshi, Uruguayan, and Japanese populations were taken from the reports of Hossain and Yamanaka (2019), Stewart et al. (2019), and Yamanaka et al. (2015a), respectively. Data of Brazil, Paraguay, and Argentina were obtained from Akamatsu et al. $(2013,2017)$. Four Mexican samples of 2015 (three from Tamaulipas and one from San Luis Potosi) previously reported (García-Rodríguez et al. 2017) are also included. The numbers at the nodes indicate approximately unbiased $P$ values $(>60 \%)$ generated by 10,000 multiscale bootstrap resamplings.

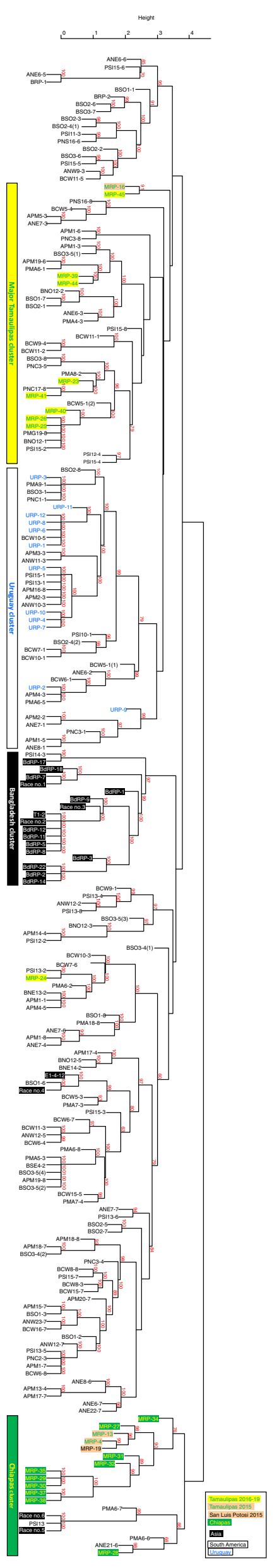


and Rpp3 of PI 452312 (Fig. 1). As a result, none of the 19 MRPs of 2016 to 2019 showed the same pathotypes as the 4 MRPs of 2015 with decreasing virulence to resistance genes.

\section{DISCUSSION}

Clear differences in the reaction patterns were observed between MRPs collected in Tamaulipas and those collected in Chiapas. Differences in virulence against resistance genesspecifically Rppl of PI 200492, Rppl-b of PI 587880A and PI 594767A, Rpp 2 of PI 230970, and Rpp3 of PI 462312 (Table 4)-were revealed in the clustering dendrogram (Figs. 1 and 2). In addition, reaction patterns differed among the four seasons (2015 summer, 2016-2017 winter, 2018 summer, and 20182019 winter), as well as between the two states: Tamaulipas and Chiapas. Therefore, both geographical and seasonal pathogenic changes were clearly identified.

Tamaulipas and Chiapas, localized at a geographical distance of approximately $1,000 \mathrm{~km}$, have climatic differences. During the period with the highest probability for the occurrence of ASR in Mexico (October to March), the temperature is higher in Chiapas $\left(22\right.$ to $\left.29^{\circ} \mathrm{C}\right)$ than in Tamaulipas $\left(\leq 18^{\circ} \mathrm{C}\right)$. In contrast, the precipitation is higher in Tamaulipas (60 to $400 \mathrm{~mm}$ ) than in Chiapas ( $\geq 60 \mathrm{~mm}$; Vidal-Zepeda 2005). Both temperature and precipitation conditions in Tamaulipas are caused by the effect of the climatic event called "north," referring to cold winds from North America that hit high-temperature areas and are loaded with humidity and precipitate. Chiapas is isolated from this climatic phenomenon due to a geographical barrier constituted by the mountains of the north of Chiapas (Vidal-Zepeda 2005). There is no scientific evidence that this kind of climatic difference between the two states might cause the difference in the virulence characteristics of the ASR pathogen. Regarding host soybean, no commercial variety is known as ASR-resistant with Rpp genes in Mexico. In addition, the soybean cultivation area in Mexico is 280 thousand ha, less than $1 \%$ compared with the United States and Brazil. Thus, high selection pressure of virulence in the ASR pathogen does not seem to be expected. Epidemiological surveys in the area around the two states are needed to determine the cause of the difference in the virulence characteristics of the ASR pathogen.

Temporal and geographic variations of ASR populations have been reported previously in the United States. Twizeyimana and Hartman (2012) indicated that ASR isolates from the South of the United States (the region closest to Mexico) were more diverse than those from central and southeast regions. Furthermore, three pathotypes were found in 2008 , whereas only two pathotypes were observed in both 2007 and 2009, and only one pathotype was found in 2006. Interestingly, the Rpp genes that distinguished virulence between the samples from Tamaulipas and Chiapas [Rppl (PI 200492), Rpp2 (PI 230970), and Rpp3 (PI 462312)] were resistant to most of the P. pachyrhizi samples in the United States ( $\mathrm{Li}$ 2009; Li et al. 2012; Paul et al. 2015, 2021; Twizeyimana and Hartman 2012), as well as samples of Chiapas in 2018. In contrast, in Tamaulipas in the 2016 to 2019 period, most of the reactions to these differentials were susceptible. In 2004, susceptibility of both Rppl (PI 200492) and Rpp3 (PI 462312) was reported in the United States (Paul et al. 2015) when ASR appeared for the first time in North America (Schneider et al. 2005). However, in the United States, the virulence to these resistant varieties has not been detected in more recent years (Paul and Hartman 2009; Pham et al. 2009; Walker et al. 2014). The ineffectiveness of Rppl-b in the United States (Li 2009; Walker et al. 2014) was also observed in Tamaulipas and San Luis Potosi during 2015 (García-Rodríguez et al. 2017) and in Chiapas in 2018. Therefore, Tamaulipas samples can be considered to have lost virulence to Rppl-b from 2016 to 2019 (Fig. 1). This avirulence to Rppl-b is one of the major characteristics of the South American pathogen because more than $85 \%$ of ASR samples were avirulent (Table 4). As a result, a clear difference of virulence was detected between the two states in Mexico. The Tamaulipas strains have pathogen characteristics similar to the South American ones, and the Chiapas strains have similar pathogenicity to the North American ones. Nevertheless, such geographical differences in pathogenicity were not observed in South American strains (Akamatsu et al. 2013, 2017; Stewart et al. 2019). Murithi et al. (2020) reported the pathogenicity of East-African ASR using 11 differentials carrying the same Rpps as were used in the present study. None of the 23 MRPs identified here corresponded to 12 East-African pathotypes because EastAfrican pathogens are all avirulent to Rpp1-b, Rpp2, and Rpp3 but virulent to Rppl.

Rppl (PI 200492 and PI 587886) was ineffective against MRPs from Tamaulipas and recorded 7.7 and $0.0 \%$ for the frequency of $\mathrm{R}$ reactions, respectively (Table 4), as observed in South America (Akamatsu et al. 2013, 2017; Stewart et al. 2019). However, PI 200492 (Rppl) recorded a high level of resistance in Chiapas (Table 4). PI 200492 (Rppl) has shown resistance in the United States, Japan, and Bangladesh (Hossain and Yamanaka 2019; Li 2009; Li et al. 2012; Twizeyimana and Hartman 2012; Walker et al. 2014; Yamaoka et al. 2014), as well as Mexico in 2007 (Peña-del-Río et al. 2014). However, previous reports indicated that soybean genotypes with Rppl (PI 200492) were susceptible to ASR populations collected in Taiwan in 1972 and 1980, the Philippines in 1977, South Africa in 2001, Thailand and Zimbabwe in 2001, and Japan from 1993 to 1997 (Bonde et al. 2006; Bromfield et al. 1980; Paul et al. 2015; Pham et al. 2009; Ray et al. 2009; Yamaoka et al. 2002), as well as in Tamaulipas (Table 4). This phenomenon also appeared in Rpp2 and Rpp3 of PI 462312. However, the high frequency of $\mathrm{R}$ reactions from Rpp3 in Chiapas (Table 4) was also observed in the previous study (García-Rodríguez et al. 2017). Thus, approximately half of MRPs evaluated in this study are virulent to Rppl (PI 200492), Rpp2, and Rpp3 (PI 462312), evidencing virulence diversity of $P$. pachyrhizi in Mexico.

Rppl-b showed 34.8 to $52.2 \%$ resistance to all MRPs (Table 4). However, most of the $\mathrm{R}$ reactions were observed in Tamaulipas samples (Fig. 1B), similar to results from Japan, Bangladesh, and South America (Akamatsu et al. 2013, 2017; Hossain and Yamanaka 2019; Yamaoka et al. 2014). In contrast, most of the S reactions were detected in Chiapas samples and samples in 2015 (Fig. 1B). High susceptibility of Rppl-b was also observed in the United States (Li 2009; Walker et al. 2014). The similarity in virulence between Chiapas and the United States was also observed in Rpp3 of PI 462312: It caused R reactions to most of Chiapas and United States pathogens (Fig. 1B; Paul et al. 2015; Walker et al. 2014), as well as those in Japan and Bangladesh (Hossain and Yamanaka 2019; Yamaoka et al. 2014). In contrast, this differential caused $S$ reactions in most cases in South America (Akamatsu et al. 2017; Stewart et al. 2019), exactly as observed in Tamaulipas (Fig. 1B).

PI 200526 (Rpp5) was the unique resistant line that recorded $100 \%$ of R reactions in Mexico from 2016 to 2019, even though one MRP from 2015 was virulent to this variety (Fig. 1B). This variety has a high frequency of resistance to not only the Mexican pathogen (95.7\%) but also the South American pathogen $(76.6 \%$; Table 4), as well as Japanese and Bangladeshi strains (100\%; Hossain and Yamanaka 2019). However, it was susceptible to 24 U.S. strains, even though MRPs from Chiapas have the same characteristics of virulence to PI 200492 (Rppl), PI 587880A 
(Rppl-b), PI 594767A (Rppl-b), PI 230970 (Rpp2), PI 462312 (Rpp3), and PI 567102B (Rpp6) as the U.S. pathogen reported by Paul et al. (2015). Thus, PI 200526 is a valuable resistant variety to distinguish Mexican and U.S. ASR pathogens with similar virulence.

Rpp3 (PI 416764), Rpp4, and Rpp6 conferred a similar level of resistance to the Mexican pathogen (52.2 to 69.6\%; Table 4). This Rpp3-mediated resistance has also been reported in other countries, and the frequency of $\mathrm{R}$ reactions varied widely (Bonde et al. 2006; García-Rodríguez et al. 2017; Maphosa et al. 2013; Murithi et al. 2017; Paul et al. 2015, 2021; Pham et al. 2009; Twizeyimana et al. 2011). However, in Bangladesh and Japan, PI 416764 was effective in $P$. pachyrhizi pathotypes (Hossain and Yamanaka 2019; Yamaoka et al. 2014). For Rpp4, the number of $\mathrm{R}$ reactions increased in Mexico from the 2015 summer to the 2018-2019 winter. Rpp6 is relatively effective against ASR strains from most soybean-growing areas in the world (Hossain and Yamanaka 2019), mainly in South America and Japan (Akamatsu et al. 2013); nevertheless, this gene was ineffective against all tested $P$. pachyrhizi strains from Bangladesh (Hossain and Yamanaka 2019). That shows the uniqueness of the Mexican ASR pathogen.

In this study, the Mexican ASR pathogen revealed clearly different reactions between differential varieties carrying Rppl or Rpp3. Contrast phenotypes were shown between two Rpplcarrying varieties, PI 587886 and PI 200492 in Chiapas, and between two Rpp3-carrying varieties, PI 462312 and PI 416764 in Tamaulipas, respectively (Fig. 1). Resistance loci of PI 587886 and PI 200492 were mapped at the same chromosomal position as Rpp1 (Hyten et al. 2007; Ray et al. 2009). Additionally, resistance locus Rpp3 was mapped in PI 462312 and PI 416764 (Hossain et al. 2015; Hyten et al. 2009). However, different reactions between PI 587886 and PI 200492, and between PI 462312 and PI 416764, were also observed in Japanese and Brazilian strains (Aoyagi et al. 2020). In both Rppl and Rpp3 cases, two varieties might have different resistant alleles of the same gene or different genes closely located in the same resistance gene cluster.

This study also corroborated the strong resistance of the Rpppyramided line No6-12-1 carrying Rpp2, Rpp4, and Rpp5 because it was completely resistant to all tested MRPs, including the 2015 samples (García-Rodríguez et al. 2017). This soybean line was previously identified to have a broader spectrum and a higher level of resistance than its ancestors carrying a single gene (Hossain and Yamanaka 2019; Murithi et al. 2020; Stewart et al. 2019; Yamanaka and Hossain 2019; Yamanaka et al. 2013, 2015b). In this study, a minimum level of sporulation $(\mathrm{SL}=0.1)$ was observed only in MRP-31, and no urediniospore production was detected in the other MRP samples. Considering the fact that no MRP showed virulence to this line and no single$R p p$-carrying variety was effective against all MRPs, introducing a single gene is not effective to control ASR in Mexico. Line No6-12-1 is one of the best candidates of a resistant donor to develop soybean varieties with durable resistance to $P$. pachyrhizi in Mexico.

In conclusion, $P$. pachyrhizi samples of Tamaulipas and Chiapas states have differing virulence derived from contrasting reactions on four individual resistance genes: Rppl, Rppl-b, Rpp2, and Rpp3. The major North American P. pachyrhizi pathogen has the characteristics of virulence to Rppl- $b$ and avirulence to Rppl and Rpp3, just like the pathogen from Chiapas. On the other hand, the South American pathogen has similar virulence to Tamaulipas samples, including Rppl and Rppl-b. The $1,000 \mathrm{~km}$ distance and different climates between the two states in Mexico appear to contribute to a big difference in the pathogenicity of the North and South American ASR pathogens.
The fact that the ASR pathogen had similar virulence to the South American ones, dominant in Tamaulipas (Mexican state next to Texas) warns us against the outbreak of South American ASR pathotypes in the United States.

\section{ACKNOWLEDGMENTS}

We are grateful to the Brazilian Agricultural Research Corporation (Embrapa) for providing seeds of differential varieties, except for No612-1. We are deeply grateful to Ing. Iván Ausencio Delgado-Rodríguez (CESAVETAM, Altamira) for his help during the collection of ASR samples in Tamaulipas. This study was conducted under the JIRCAS research project "Development of technologies for the control of migratory plant pests and transboundary diseases."

\section{LITERATURE CITED}

Akamatsu, H., Yamanaka, N., Soares, R. M., Ivancovich, A. J. G, Lavilla, M. A., Bogado, A. N., Morel, G., Scholz, R., Yamaoka, Y., and Kato, M. 2017. Pathogenic variation of South American Phakopsora pachyrhizi populations isolated from soybeans from 2010 to 2015. Jpn. Agric. Res. Q. 51:221-232.

Akamatsu, H., Yamanaka, N., Yamaoka, Y., Soares, R. M., Morel, W., Ivancovich, A. J. G., Bogado, A. N., Kato, M., Yorinori, J. T., and Suenaga, K. 2013. Pathogenic diversity of soybean rust in Argentina, Brazil, and Paraguay. J. Gen. Plant Pathol. 79:28-40.

Aoyagi, L. N., Muraki, Y., and Yamanaka, N. 2020. Characterization of three soybean landraces resistant to Asian soybean rust disease. Mol. Breed. (Online) 40:53.

Bonde, M. R., Nester, S. E., Austin, C. N., Stone, C. L., Frederick, R. D. Hartman, G. L., and Miles, M. R. 2006. Evaluation of virulence of Phakopsora pachyrhizi and P. meibomiae isolates. Plant Dis. 90: 708-716.

Bromfield, K. R., Melching, J. S., and Kingsolver, C. H. 1980. Virulence and aggressiveness of Phakopsora pachyrhizi isolates causing soybean rust. Phytopathology 70:17-21.

Cárcamo-Rodríguez, A., Ríos, J. A., and Hernández, J. R. 2006. First report of Asian soybean rust caused by Phakopsora pachyrhizi from Mexico. Plant Dis. 90:1260-1260.

Childs, S. P., King, Z. R., Walker, D. R., Harris, D. K., Pedley, K. F., Buck, J. W., Boerma, H. R., and Li, Z. 2018. Discovery of a seventh Rpp soybean rust resistance locus in soybean accession PI 605823. Theor. Appl. Genet. 131:27-41.

Garcia, A., Calvo, E. S., de Souza Kiihl, R. A., Harada, A., Hiromoto, D. M. and Vieira, L. G. E. 2008. Molecular mapping of soybean rust (Phakopsora pachyrhizi) resistance genes: Discovery of a novel locus and alleles. Theor. Appl. Genet. 117:545-553.

García-Rodríguez, J. C., Ascencio, L. G., and Vicente H. Z. 2019. Resistencia de variedades nacionales de soya a la roya asiática Phakopsora pachyrhizi. Transversalidad Cient. Tecnol. 3:126-132 (in Spanish).

García-Rodríguez, J. C., Morishita, M., Kato, M., and Yamanaka, N. 2017. Características patogénicas de la roya asiática de la soya (Phakopsora pachyrhizi) en México. Rev. Mex. Fitopatol. 35:338-349.

Hartman, G. L., West, E. D., and Herman, T. K. 2011. Crops that feed the world 2. Soybean-worldwide production, use, and constraints caused by pathogens and pests. Food Secur. 3:5-17.

Hartwig, E. E. 1986. Identification of a fourth major gene conferring resistance to soybean rust. Crop Sci. 26:1135-1136.

Hartwig, E. E., and Bromfield, K. R. 1983. Relationships among three genes conferring specific resistance to rust in soybeans. Crop Sci. 23: 237-239.

Hossain, M. M., Akamatsu, H., Morishita, M., Mori, T., Yamaoka, Y., Suenaga, K., Soares, R. M., Bogado, A. N., Ivancovich, A. J. G, and Yamanaka, N. 2015. Molecular mapping of Asian soybean rust resistance in soybean landraces PI 594767A, PI 587905 and PI 416764. Plant Pathol. 64:147-156.

Hossain, M. M., and Yamanaka, N. 2019. Pathogenic variation of Asian soybean rust pathogen in Bangladesh. J. Gen. Plant Pathol. 85:90-100.

Hyten, D. L., Hartman, G. L., Nelson, R. L., Frederick, R. D., Concibido, V. C., Narvel, J. M., and Cregan, P. B. 2007. Map location of the Rppl locus that confers resistance to soybean rust in soybean. Crop Sci. 47: 837-840.

Hyten, D. L., Smith, J. R., Frederick, R. D., Tucker, M. L., Song, Q., and Cregan, P. B. 2009. Bulked segregant analysis using the GoldenGate assay to locate the Rpp3 locus that confers resistance to soybean rust in soybean. Crop Sci. 49:265-271. 
Ishikawa-Ishiwata, Y., and Furuya, J. 2021a. Fungicide cost reduction with soybean rust-resistant cultivars in Paraguay: A supply and demand approach. Sustainability 13:887.

Ishikawa-Ishiwata, Y., and Furuya, J. 2021b. Soybean rust and resistant cultivar effects on global soybean supply and demand. Jpn. Agric. Res. Q. 55:59-67.

Li, S. 2009. Reaction of soybean rust-resistant lines identified in Paraguay to Mississippi isolates of Phakopsora pachyrhizi. Crop Sci. 49:887-894.

Li, S., Smith, J. R., Ray, J. D., and Frederick, R. D. 2012. Identification of a new soybean rust resistance gene in PI 567102B. Theor. Appl. Genet. 125:133-142.

Li, X., Esker, P. D., Pan, Z., Dias, A. P., Xue, L., and Yang, X. B. 2010. The uniqueness of the soybean rust pathosystem: An improved understanding of the risk in different regions of the world. Plant Dis. 94:796-806.

Maphosa, M., Talwana, H., and Tukamuhabwa, P. 2013. Assessment of comparative virulence and resistance in soybean using field isolates of soybean rust. J. Agric. Sci. 5:249-257.

Murithi, H. M., Haudenshield, J. S., Beed, F., Mahuku, G., Joosten, M. H. A. J., and Hartman, G. L. 2017. Virulence diversity of Phakopsora pachyrhizi isolates from East Africa compared to a geographically diverse collection. Plant Dis. 101:1194-1200.

Murithi, H. M., Soares, R. M., Mahuku, G., Esse, P. V., and Joosten, M. H. A. J. 2020. Diversity and distribution of pathotypes of the soybean rust fungus Phakopsora pachyrhizi in East Africa. Plant Pathol. 70:655-666.

Paul, C., Frederick, R. D., Hill, C. B., Hartman, G. L., and Walker, D. R. 2015. Comparison of pathogenic variation among Phakopsora pachyrhizi isolates collected from the United States and international locations, and identification of soybean genotypes resistant to the U.S. isolates. Plant Dis. 99:1059-1069.

Paul, C., Harris, D. K., Li, Z., Bollich, P. A., and Walker, D. R. 2021. Reactions of 52 soybean germplasm accessions with Rpp3 alleles to a panel of 13 Phakopsora pachyrhizi (soybean rust) isolates from the southern United States. J. Gen. Plant Pathol. 87:55-70.

Paul, C., and Hartman, G. L. 2009. Sources of soybean rust resistance challenged with single-spored isolates of Phakopsora pachyrhizi. Crop Sci. 49:1781-1785.

Peña-del-Río, M. L. Á., Maldonado-Moreno, N., and Diaz-Franco, A. 2014. Reaction of soybean germplasm to Phakopsora pachyrhizi in the field. Rev. Fitotec. Mex. 37:225-227.

Pennisi, E. 2010. Armed and dangerous. Science 327:804-805.

Pham, T. A., Miles, M. R., Frederick, R. D., Hill, C. B., and Hartman, G. L. 2009. Differential responses of resistant soybean entries to isolates of Phakopsora pachyrhizi. Plant Dis. 93:224-228.

R Development Core Team. 2019. R: A Language and Environment for Statistical Computing. http://www.r-project.org/.

Ray, J. D., Morel, W., Smith, J. R., Frederick, R. D., and Miles, M. R. 2009. Genetics and mapping of adult plant rust resistance in soybean PI 587886 and PI 587880A. Theor. Appl. Genet. 119:271-280.

Rosa, C. R. E., Spehar, R. C., and Liu, Q. J. 2015. Asian soybean rust resistance: An overview. J. Plant Pathol. Microbiol. 6:307.

SAGARPA. 2017. Planeación Agrícola Nacional 2017-2030. Oleaginosas. https://www.gob.mx/cms/uploads/attachment/file/256431/B_sicoOleaginosas-parte_una.pdf (accessed March 8, 2021).

Schneider, R. W., Hollier, C. A., Whitam, H. K., Palm, M. E., McKemy, J. M., Hernández, J. R., Levy, L., and DeVries-Paterson, R. 2005. First report of soybean rust caused by Phakopsora pachyrhizi in the continental United States. Plant Dis. 89:774

SIAP. 2021. Avance de siembras y cosechas. https://nube.siap.gob.mx/ avance_agricola/ (accessed March 8, 2021).

Stewart, S., Rodríguez, M., and Yamanaka, N. 2019. Pathotypic variation of Phakopsora pachyrhizi isolates from Uruguay. Trop. Plant Pathol. 44: 309-317.
Suzuki, R., and Shimodaira, H. 2006. Pvclust: An R package for assessing the uncertainty in hierarchical clustering. Bioinformatics 22 : 1540-1542.

Terán-Vargas, A. P., Ascencio-Luciano, G., Maldonado-Moreno, N., and Avila-Valdez, J. 2007. La roya asiática de la soya en México. Centro de Investigación Regional del Noreste-INIFAP, Altamira, Mexico.

Twizeyimana, M., and Hartman, G. L. 2012. Pathogenic variation of Phakop sora pachyrhizi isolates on soybean in the United States from 2006 to 2009. Plant Dis. 96:75-81.

Twizeyimana, M., Ojiambo, P. S., Haudenshield, J. S., Caetano-Anollés, G., Pedley, K. F., Bandyopadhyay, R., and Hartman, G. L. 2011. Genetic structure and diversity of Phakopsora pachyrhizi isolates from soyabean. Plant Pathol. 60:719-729.

USDA. 2021. Oilseeds and products annual. https://apps.fas.usda.gov/new gainapi/api/Report/DownloadReportByFileName?fileName=Oilseeds $\%$ 20and\%20Products\%20Annual_Mexico\%20City_Mexico_04-01-2020 $\% 20$ (accessed on Dec 10, 2021).

Vidal-Zepeda, R. 2005. Las regiones climáticas de México. Instituto de Geografpia, UNAM, Mexico. http://www.publicaciones.igg.unam.mx/ index.php/ig/catalog/view/42/42/128-1 (accessed March 8, 2021)

Walker, D. R., Harris, D. K., King, Z. R., Li, Z., Boerma, H. R., Buckley, J. B., Weaver, D. B., Sikora, E. J., Shipe, E. R., Mueller, J. D., Buck, J. W., Schneider, R. W., Marois, J. J., Wright, D. L., and Nelson, R. L. 2014. Evaluation of soybean germplasm accessions for resistance to Phakopsora pachyrhizi populations in the southeastern United States, 2009-2012. Crop Sci. 54:1673-1689.

Yamanaka, N., and Hossain, M. M. 2019. Pyramiding three rust-resistance genes confers a high level of resistance in soybean (Glycine max). Plant Breed. 138:686-695.

Yamanaka, N., Hossain, M. M., and Yamaoka, Y. 2015a. Molecular mapping of Asian soybean rust resistance in Chinese and Japanese soybean lines, Xiao Jing Huang, Himeshirazu, and Iyodaizu B. Euphytica 205: 311-324.

Yamanaka, N., Kato, M., Akamatsu, H., and Yamaoka, Y. 2020. Laboratory manual for studies on soybean rust resistance (version 25). Japan International Research Center for Agricultural Sciences (JIRCAS). https://www.jircas.go.jp/en/publication/manual_guideline/30 (accessed March 1, 2021)

Yamanaka, N., Lemos, N. G., Uno, M., Akamatsu, H., Yamaoka, Y., Abdelnoor, R. V., Braccini, A. L., and Suenaga, K. 2013. Resistance to Asian soybean rust in soybean lines with the pyramided three Rpp genes. Crop Breed. Appl. Biotechnol. 13:75-82.

Yamanaka, N., Morishita, M., Mori, T., Lemos, N. G., Hossain, M. M., Akamatsu, H., Kato, M., and Yamaoka, Y. 2015b. Multiple Rpp-gene pyramiding confers resistance to Asian soybean rust isolates that are virulent on each of the pyramided genes. Trop. Plant Pathol. 40:283-290.

Yamaoka, Y., Fujiwara, Y., Kakishima, M., Katsuya, K., Yamada, K., and Hagiwara, H. 2002. Pathogenic races of Phakopsora pachyrhizi on soybean and wild host plants collected in Japan. J. Gen. Plant Pathol. 68 52-56.

Yamaoka, Y., Yamanaka, N., Akamatsu, H., and Suenaga, K. 2014 Pathogenic races of soybean rust Phakopsora pachyrhizi collected in Tsukuba and vicinity in Ibaraki, Japan. J. Gen. Plant Pathol. 80: 184-188.

Yáñez-López, R., Hernández-Zul, M. I., Quijano-Carranza, J. A., TeránVargas, A. P., Pérez-Moreno, L., Díaz-Padilla, G., and Rico-García, E. 2015. Potential distribution zones for soybean rust (Phakopsora pachyrhizi) in Mexico. Ecosistemas Recur. Agropecuarios 2:291-302.

Yorinori, J. T., Paiva, W. M., Frederick, R. D., Costamilan, L. M., Bertagnolli, P. F., Hartman, G. E., Godoy. C. V., and Nunes, J. 2005. Epidemics of soybean rust (Phakopsora pachyrhizi) in Brazil and Paraguay from 2001 to 2003. Plant Dis. 89:675-677. 